BIOMEDICAL AND BIOSOCIAL ANTHROPOLOGY
$\begin{gathered}\text { Official Journal of the International Academy } \\ \text { of Integrative Anthropology } \\ \text { journal homepage: http://bba-journal.com }\end{gathered}$

\title{
Sleep disturbances and related occupational diseases in Ukrainian firefighters
}

\author{
Sukholentsev A. N. ${ }^{1}$, Kraisvitniy A. I. ${ }^{2}$, Kovalchuk V. B. ${ }^{2}$, Cherniy V. P.. ${ }^{3}$ Kovalchuk N. D. \\ ${ }^{1}$ State Emergency Service of Ukraine in Kirovohrad region, Kropyvnitskiy, Ukraine; \\ 2Donetsk National Medical University, Kropyvnitskiy, Ukraine; \\ ${ }^{3}$ Central Ukrainian State Pedagogical University named after V. Vynnychenko, Kropyvnitskiy, Ukraine; \\ ${ }^{4}$ Minor Academy of Sciences of Gifted School Youth, Kropyvnitskiy, Ukraine
}

\section{ARTICLE INFO}

Received: 7 September, 2018

Accepted: 31 October, 2018

UDC: 613.6

CORRESPONDING AUTHOR

e-mail:vk65nk02@gmail.com Kovalchuk V. B.

\begin{abstract}
Sleep deprivation is one of the main professionally determined factors for firefighters which can decrease their executive functioning and contribute to an array of health problems in them, including cardiovascular disease, diabetes, and depression mood disorders. The aim of this research is to gather preliminary data regarding the health of Ukrainian, with a focus on sleep quality indicators. Sleep-deprived participants in our research study were identified using such questionnaires as PSQI, ISI, ESS, SSS, FSS, and BQSA. Statistical processing of the data was carried out with the aid of Fisher's exact test, a statistical tool which is widely used in medical researches when the expected numbers are small. The obtained results confirm the presence of certain regularities. First, typical for the firefighting profession sleep disorders were detected among workers of operatively rescue service of Kropyvnitskiy city: including daytime fatigue, low sleep quality, insomnia, apnea, restless leg syndrome, low alertness, daytime sleepiness. Secondly, individuals suffering from sleep deprivation are at a higher risk for developing certain cardiovascular and metabolic diseases, depressive disorders, including increased impulsivity and overall lack of executive functioning. Thirdly, the importance of early detection and treatment for sleep disorders as a protective measure against the development of the aforementioned diseases has been stressed in our study. Sleep hygiene education should be provided to Ukrainian firefighters. It could influence them to make better choices related to their sleep, which would subsequently impact other areas of their health and wellbeing. Annual research studies concerning firefighters' sleep quality should be conducted in Ukraine on a regular basis with the aim to accumulate relevant statistics on the topic under consideration.
\end{abstract}

Keywords: sleep disorders, executive functioning, occupational health, occupational disease, protective (preventive) medicine.

\section{Introduction}

The future belongs to preventive medicine (Mykola Pyrogov)

At the time of scientific and technological progress, high level of stressfulness in human society and harmful effects of external environmental factors, the issue of health, and sleep as its essential component, is getting more and more significant regarding all fields of human activity and, first of all, those workers whose job is related to health risks, psychological tension, sleep deprivation and at the same time is of great importance for the entire community [6].

The relevance of this scientific research is stipulated by an urgent need for Ukrainian firefighters to change their attitudes to the quality of their sleep (sleep hygiene), taking into consideration the fact that their executive functioning is inseparable from shift work, unfavorable conditions and extreme situations. That means that they must attend to their occupational health, fitness and all aspects of occupational longevity. They should sustain the appropriate level of all functional systems of their body, developing in themselves a positive predisposition towards their jobs, good morale, value judgment, self-discipline and patriotism.

Sleep medicine has been developing intensively throughout a few decades, but the keen interest in health issues with a focus on sleep has increased immensely these days which is witnessed by the latest experimental researches in this field led by Esra Tasali [23], Mathew 
Walker [28], Joelle Adrian [2], Volodymyr Koval'zon [19], Mykhailo Poluektov [20], scientists from M.D. Strazhesko Institute of Cardiology [21]. Experts state [18, 25] that lowquality, insufficient sleep, disturbed by shift work or any other external factor, aggravates daytime sleepiness and leads to a variety of changes in every neural and endocrine function of the human body including the increased level of stress hormones, cognitive and metabolic disorders, low level of immunity and risk factors for cancer and cardiovascular disease. The excessive light stimulation, and active behaviours at night are becoming most popular causes for circadian rhythm disorders and their further distabilisation (cognitive distortions).

The aim of this research is to gather preliminary data regarding the health of Ukrainian, with a focus on sleep quality indicators.

\section{Materials and methods}

The research study included firefighters of fire department units of the State Emergency Service of Ukraine in Kirovohrad oblast', which are located in the city of Kropyvnytskiy. Participants were professional firefighters regardless of their age, education and years of employment. While on duty, all of them work overnight shifts and respond to a wide range of incidents, including fires, explosions, terrorist events, mass-casualty incidents, motor vehicle accidents, ice/water rescues, and natural disasters. All subjects had to complete six questionnaires including the Pittsburg Sleep Quality Index (PSQI), the Insomnia Severity Index (ISI), the Epworth Sleepiness Scale (ESS), the Stanford Sleepiness Scale (SSS), the Fatigue Severity Scale (FSS) and the Berlin Questionnaire for Sleep Apnea (BQSA).

Rescuers took part in the survey research on a voluntary basis on condition of anonymity (their names were given by the authority under special codes). To make our testing convenient (it took 40-45 minutes), we offered tests in paper format either in Ukrainian or Russian, at the choice of each participant. 130 firefighters agreed to take part in the experiment and 124 of them gave full answers concerning their anthropometric measures and sleep hygiene. This array of information constitutes the basis for making conclusions and working out recommendations. Statistical processing of data was carried out with the aid of Fisher's exact test.

\section{Results}

Results from the conducted survey research show some interesting patterns.

The data we obtained concerning sleep deprivation in Ukrainian firefighters, correlate with similar values in representatives of rescue services from other countries. The statistics show that 37.2 percent of French [24, 27] and 59 percent of American firefighters are dissatisfied with the quality of their sleep $[4,5,11,12]$. Among the firefighters from the Seoul Metropolitan Area (South Korea) 78.8 percent of firefighters have sleep problems [17]. In China 70 percent of
Table 1. Demographic characteristics of participants.

\begin{tabular}{|c|c|c|c|c|}
\hline \multirow[b]{2}{*}{ Indexes } & \multirow{2}{*}{$\begin{array}{l}\text { Row } \\
\text { total }\end{array}$} & \multicolumn{3}{|c|}{ Age categories } \\
\hline & & $\begin{array}{l}\leq 30 \\
\text { years }\end{array}$ & $\begin{array}{l}31-40 \\
\text { years }\end{array}$ & $\begin{array}{l}>40 \\
\text { years }\end{array}$ \\
\hline The number of participants & 124 & 54 & 47 & 23 \\
\hline The mean age of participants (years) & 32,80 & 25,83 & 35,74 & 43,13 \\
\hline $\begin{array}{l}\text { The average BMI range (body mass } \\
\text { index, } \mathrm{kg} / \mathrm{m}^{2} \text { ) }\end{array}$ & 26,09 & 25,33 & 26,85 & 26,32 \\
\hline $\begin{array}{l}\text { Have characteristics of obesity, } \\
\qquad \mathrm{BMI}>30\end{array}$ & 13 & 3 & 9 & 1 \\
\hline Have high blood pressure & 13 & 2 & 4 & 7 \\
\hline Heavy smokers & 37 & 15 & 18 & 4 \\
\hline Diabetics & 0 & 0 & 0 & 0 \\
\hline Consume alcohol in large quantities & 0 & 0 & 0 & 0 \\
\hline
\end{tabular}

Table 2. The detected sleep disturbances in firefighters of Kropyvnytskiy city (the years 2018).

\begin{tabular}{|c|c|c|}
\hline Sleep disturbances & $\begin{array}{c}\text { Survey } \\
\text { Questionnaires }\end{array}$ & Total scores \\
\hline Low sleep quality & PSQI & $\begin{array}{l}\text { Satisfied by the main sleep- } \\
76,81 \% \\
\text { Non-satisfied by the main } \\
\text { sleep- } 24,19 \%\end{array}$ \\
\hline Insomnia & ISI & $\begin{array}{l}\text { Not found }-95,16 \% \\
\text { Is found }-04,84 \%\end{array}$ \\
\hline Daytime sleepiness & ESS & $\begin{array}{l}\text { Non-significant, does not } \\
\text { influence job performance - } \\
92,74 \% \\
\text { Significant, may influence job } \\
\text { performance - } 07,26 \%\end{array}$ \\
\hline $\begin{array}{c}\text { Alertness, executive } \\
\text { functioning at } \\
\text { daytime }\end{array}$ & SSS & $\begin{array}{l}\text { High level - 86,71\% } \\
\text { Low level - 14,29\% }\end{array}$ \\
\hline Daytime fatigue & FSS & $\begin{array}{l}\text { Non-significant, does not } \\
\text { influence job performance - } \\
68,55 \% \\
\text { Significant, may influence job } \\
\text { performance - } 31,45 \%\end{array}$ \\
\hline Apnea (OSAS) & BQSA & $\begin{array}{l}\text { Not found }-89,00 \% \\
\text { Symptoms are found }-11,00 \%\end{array}$ \\
\hline $\begin{array}{c}\text { Restless Leg } \\
\text { Syndrome (RLS) }\end{array}$ & PSQI & $\begin{array}{l}\text { Not found }-95,80 \% \\
\text { Is found - } 04,20 \%\end{array}$ \\
\hline
\end{tabular}

firefighters complain about low quality of their main sleep [13]. For Iranian and British rescue workers this rate is 69.9 and 61 percent.

According to age categories we classify the obtained experimental data as it is shown in table 3 .

On the basis of the above, it may be concluded that in younger firefighters of our city stand out the parameters of an excessively high rate of daytime fatigue and decreased physical activity; middle aged firefighters have two high rate variables - dissatisfaction with their sleep and daytime sleepiness and older rescuers have such critically high quantitative variables as decreased alertness in the daytime and apnea. These data explain firefighters' predisposition to certain occupational illnesses and we have to prove this hypothesis with the aid of an appropriate method of 
Table 3. The distribution of sleep deprivation variables in firefighters of Kropyvnytskiy city (the year 2018).

\begin{tabular}{|c|c|c|c|c|}
\hline \multirow[b]{2}{*}{ Parameters } & \multirow{2}{*}{$\begin{array}{l}\text { Row } \\
\text { total }\end{array}$} & \multicolumn{3}{|c|}{ Age categories } \\
\hline & & $\begin{array}{l}\text { Younger } \\
(n=54)\end{array}$ & $\begin{array}{c}\text { Middle-aged } \\
(\mathrm{n}=47)\end{array}$ & $\begin{array}{l}\text { Older } \\
(n=23)\end{array}$ \\
\hline $\begin{array}{l}\text { Dissatisfied with sleep } \\
\text { quality (\%) }\end{array}$ & 24,19 & 10,49 & 10,48 & 03,23 \\
\hline Insomnia (\%) & 04,84 & 01,61 & 01,61 & 01,61 \\
\hline Daytime sleepiness (\%) & 07,26 & 01,61 & 04,03 & 01,61 \\
\hline $\begin{array}{l}\text { Decreased alertness } \\
\text { (efficiency) (\%) }\end{array}$ & 14,29 & 03,57 & 04,76 & 05,95 \\
\hline $\begin{array}{l}\text { Daytime fatigue, physical } \\
\text { immobility (\%) }\end{array}$ & 31,45 & 12,10 & 10,48 & 08,87 \\
\hline OSAS (\%) & 11,10 & 02,20 & 03,58 & 05,23 \\
\hline RLS(\%) & 04,20 & 01,70 & 02,50 & 0 \\
\hline
\end{tabular}

Table 4. The contingency table for different age categories of subjects according to the results of the PSQI, FSS, SSS questionnaires.

\begin{tabular}{|c|c|c|c|}
\hline \multicolumn{4}{|c|}{ In the younger age group of firefighters: } \\
\hline Indexes & $\begin{array}{l}\text { Have daytime } \\
\text { fatigue (FSS) }\end{array}$ & $\begin{array}{c}\text { Have no } \\
\text { daytime } \\
\text { fatigue (FSS) }\end{array}$ & $\begin{array}{l}\text { Row } \\
\text { Total }\end{array}$ \\
\hline $\begin{array}{l}\text { Dissatisfied with their sleep } \\
\text { (PSQl) }\end{array}$ & $11(\mathrm{~A})$ & $2(\mathrm{~B})$ & 13 \\
\hline $\begin{array}{l}\text { Satisfied with the quality of } \\
\text { their sleep (PSQI) }\end{array}$ & $4(C)$ & $37(\mathrm{D})$ & 41 \\
\hline Column Total & 15 & 39 & 54 \\
\hline \multicolumn{4}{|l|}{ In middle-aged firefighters: } \\
\hline & Smokers & Non-smokers & $\begin{array}{l}\text { Row } \\
\text { Total }\end{array}$ \\
\hline $\begin{array}{l}\text { Dissatisfied with their sleep } \\
\text { (PSQI) }\end{array}$ & $11(\mathrm{~A})$ & $2(\mathrm{~B})$ & 13 \\
\hline $\begin{array}{l}\text { Satisfied with the quality of } \\
\text { their sleep (PSQI) }\end{array}$ & $7(\mathrm{C})$ & $27(\mathrm{D})$ & 34 \\
\hline Column Total & 18 & 29 & 47 \\
\hline \multicolumn{4}{|c|}{ In the older age group of firefighters: } \\
\hline & $\begin{array}{l}\text { Have daytime } \\
\text { fatigue (FSS) }\end{array}$ & $\begin{array}{c}\text { Have no } \\
\text { daytime } \\
\text { fatigue (FSS) }\end{array}$ & $\begin{array}{l}\text { Row } \\
\text { Total }\end{array}$ \\
\hline Low level of efficiency (SSS) & $5(A)$ & $0(\mathrm{~B})$ & 5 \\
\hline High level of efficiency (SSS) & $6(C)$ & $12(\mathrm{D})$ & 18 \\
\hline Column Total & 11 & 12 & 23 \\
\hline
\end{tabular}

mathematical statistics - Fisher's exact test. The needed data are placed in contingency tables as it is shown in table 4 .

We do hand calculations of Fisher's exact test according to the formula:

$P=[(A+B) ! x(C+D) ! x(A+C) ! x(B+D) !] /[A ! x B ! \times C ! x D ! x N !]$,

where $N$ is an overall number of subjects; the symbol ! indicates the factorial operator (the product of a number and a sequence of numbers each of which is less than its predecessor on 1). The calculation results show that the indicator of Fisher's exact test $(\mathrm{P})$ for the younger age group of firefighters constitutes 0.0000009 and this numeric value does not exceed the critical level of statistical significance for medical researches 0.05 and that proves the correlation between the results obtained from the two questionnaires PSQI and FSS.

Fisher's exact test $(P)$ for middle-aged firefighters equals 0.0001 and that proves the statistical relationship between the two risk factors for occupational illnesses in members of this profession. These risk factors include dissatisfaction with their sleep (according to the PSQI questionnaire) and smoking - a habit that promotes the development of atherosclerosis and cardiovascular disease and is considered to be the leading preventable cause of death in the world.

We used the aforementioned formula for computing Fisher's exact test $(P)$ for the older age group of firefighters and we got the value 0.014 , which does not exceed the critical level of statistical significance for medical researches 0.05 . In such a way we prove the relationship between the results of the FSS and SSS tests.

\section{Discussion}

Consistent, long-term sleep disturbances are tightly connected with an array of clinical disorders, which constitute a group of occupational illnesses and which with a high level of probability can develop in members of all professions related to shift work and fulfilling duties under unfavorable and extreme conditions. First of all, it regards public safety workers, who, by their vocation, must be the first to respond to various calamities in the human society and to save lives. Sleep disturbances, as one of the main risk factors in firefighting, can contribute to the development of cardiovascular disease in firefighters, as well as diabetes and depressive mood disorders.

According to the data given by The World Health Organization [29], International Association of FireFighters [13], European Fire Academy [7], Federation Nationale des Sapeurs-Pompiers de France [8]) the following groups of occupational diseases are known in the firefighting profession:

- group I - artery hypertensive heart disease which is one of the most widely-spread cardiovascular diseases, as well as myocardial infarction (heart attack), stroke, heart failure and a number of similar illnesses. $20-30 \%$ of adults throughout the world suffer from artery hypertensive heart disease. Experts from the World Health Organization (WHO) single out an array of risk factors which contribute to the development of this disease. They are as follows: - age gender - lack of exercise - smoking - alcohol abuse, excessive coffee consumption, energy drinks, as well as overweight and heredity. As usual, the active stage of artery hypertensive heart disease is provoked by overstrenuous psychic activity of a worker influenced by various psychoemotional factors[11, 18]. Highly effective in this respect are sport activities and exercise, which eliminate stress and increase muscle tone of the human body. The development of the symptoms of artery hypertensive heart disease is being provoked by such external factors as - climatic condition; - imbalanced diet (for 
instance, eating too much salt, vitamin deficiency) - low quality of drinking water; - various noises and electromagnetic fields, radiation - non-favorable conditions in the work layout including problems in communication with colleagues; unfavorable microclimate of a dwelling; - inefficient pastime. In order to prevent the development of this disease, experts say, in your working layout and at home you should control your blood pressure, systematically have medical examinations and monitor your electrocardiogram (ECG) results. One must have an individual overall exercise plan developed by a personal trainer;

- group II - diabetes. This is a metabolic disease, which results from the decreased level of insulin secretion and insulin resistance. Treating diabetes early with the aid of a diet, sugar decreasing medicines and workout routine can help prevent serious complications. Diabetes is caused by a number of genetic and individual lifestyle factors. The vast majority of patients who received this diagnosis are overweighed. Obesity by itself is a risk factor for diabetes.

- group III - depression, a serious mental health condition, the key emotional characteristics of which are a depressed mood, sadness, worthlessness and lack of interest in most normal activities. The associated symptoms include frequent headaches, fatigue, sleeping much more or much less, eating much more or much less than usual, lacking energy, suicidal thinking. Depression is caused by a combination of genetic, biological, environmental, and psychological factors. In some cases depressive mood disorders are a normal reaction to certain life circumstances and extreme situations. In our times depression is one of the most common mental disorders. Every tenth inhabitant of the planet Earth (over the age 40) experiences it. Those over 65 are three times more likely to become severely depressed. The depressive mood disorder can occur as a result of dramatic experience, for instance, passing of a relative or parent, a loss of status and loss of employment opportunities. This is a reactive depression, and it develops as a response to an external event or circumstance. A great many people who battle with early symptoms of this mental illness can recover from their condition in a half-year period through cognitive behavioral therapy, exercise training (physical activity is a very effective cure for any depression symptoms and reactive discouragement), strengthening of social communication, avoidance of conflicts in interpersonal relationships, increasing of body temperature which contributes to energy metabolism in the human body. Music therapy, art-therapy, dance therapy, aroma therapy, and work therapy can become a protective measure against depressive mood disorders and can help to maintain a high quality of life;

- group IV in this list of occupational illnesses can be constituted in the nearest future by certain kinds of cancer diseases which are currently the subject of intense research in several countries and scientists-immunologists who lead these experimental researches have just been awarded the Nobel Prize in the field of physiology and medicine (the year 2018) [3]. Now this group of diseases is not taken into consideration in our study.

Based on the findings of the current study, we analyze the quantitative variables of firefighters' predisposition to sleep related occupational illnesses. According to the results of FSS (daytime fatigue, physical inactivity), PSQI (restless leg syndrome, dissatisfaction about sleep quality), ISI (insomnia) in members of the younger age group we figure out that 20-30 year-old firefighters tend to developing depressive mood symptoms in them (group III of occupational diseases) which may be caused by a negative impact of excessive mobile telephone usage, especially in the evening, after 19.00 (these data are deserving of further investigation).

While analyzing the results of such tests as PSQI (sleep quality); ESS (daytime sleepiness); IFSS (daytime fatigue, physical inactivity); ISI (insomnia); BQSA (high blood pressure, hyperlipidemia, apnea) we monitor the predisposition of middle-aged firefighters to groups I and II of occupational illnesses - cardiovascular disease, arterial hypertension, diabetes. Special attention should be paid to further investigation of the problem of obesity and normalizing of $\mathrm{BMI}$ in this age category.

According to the results of the BQSA questionnaire (apnea, high blood pressure, hyperlipidemia) and the SSS questionnaire (alertness rate) we conclude that members of the older age category of firefighters are prone to group I of occupational illnesses, namely - cardiovascular disease, sudden cardiac arrest and getting into accidents and dangerous situations. These findings justify further exploration into the ways in which sleep disorders and cardiovascular disease relate to one another in rescue workers. And many of the firefighters who participated in this study identified a need to improve their sleep.

Based on the current researches in the field of sleep medicine $[1,10,12,17,23,26,27,28]$ scientists state that sleep deprivation, as one of the main occupational factors in firefighting, can contribute to the development of cardiovascular disease in rescue workers, as well as certain cancer diseases, diabetes and depressive mood disorders [28]. International organizations and unions of professional firefighters $[2,13,16,29]$ show that more often than civilians, firefighters are exposed to cardiovascular disease, diabetes, obesity, depressive mood disorders and suicidal attempts. Sleep deprivation and night shift work is associated with decreased alertness, vague thinking, depression [4, 12]. The obstructive sleep apnea can cause overweight, hypertension, diabetes and heart attacks. If this disease is not treated, it six times more often than in general population leads to getting into accidents and dangerous situations $[11,22,23]$. Early detection and treatment of sleep disorders using medicinal and non-medicinal methods is important in order to prevent the development of dangerous health deviations. Sleep has to become a priority in systemic researches in firefighting in order to learn its impact on all aspects of physical and mental health of firefighters of the State Emergency Service of Ukraine. 
The data obtained in this study, when compared with similar variables concerning rescue services of other countries, can constitute a basis for further accumulation of the array of statistical information in relation to sleep disturbances in full-time firefighters and prevent certain occupational illnesses in members of this profession.

\section{Conclusions}

In the course of the survey research carried out among firefighters of Kropyvnytskiy city, we detected an array of typical for the firefighting profession sleep disturbances which are caused by a number of negative occupational factors, among which we single out the necessity to work on night shifts and a high level of stressfulness of the duties they fulfill. Sleep disorders are tightly connected with the development in

\section{References}

[1] Abbasi M., Rajabi M., Yazdi Z., \& Shafikhani A. (2018). Factors Affecting Sleep Quality in Firefighters. Sleep and Hypnosis: A Journal of Clinical Neuroscience and Psychopathology, 20(4), 283-289. doi: 10.5350/Sleep.Hypn.2018.20.0163

[2] Adrian J. (2016). Sommeil et nouvelles technologies. Institut National du Sommeil et de la Vigilance.

[3] BLOG: Cancer researchers from US and Japan awarded Nobel Medicine Prize. Access mode: https://www.thelocal.se/ 20181001/live-blog-swedens-nobel-prize-in-medicine-orphysiology-2018

[4] Carey, M., Al-Zaiti, S. S., Dean, G., Sessanna, L., \& Finnell, D. (2011). Sleep Problems, Depression, Substance Use, Social Bonding and Quality of Life in Professional Firefighters. Journal of Occupational and Environmental Medicine, 53(8), 928933. doi: 10.1097/JOM.0b013e318225898f

[5] Carpenter, G., Carpenter, T., Kimbrel, N., Flynn, E., Pennington, M., Cammarata, C., Gulliver, S. (2015). Social Support, Stress, and Suicidal Ideation in Professional Firefighters. American journal of health behavior, 39(2), 191-196. doi: 10.5993/ AJHB.39.2.5

[6] Dyachkova, O. (2015). Psychological characteristics of professional rescuers in extremities. Academic notes of Kirovohrad State Pedagogical University. Series: Pedagogical sciences, 135, 109-113.

[7] European Fire Academy. Access mode: http:// europeanfireacademy.com/

[8] Federation nationale des sapeurs-pompiers de France. Access mode: https://www.pompiers.fr/federation-nationale-dessapeurs-pompiers-de-france

[9] Fryer, B. (2006). Sleep Deficit: The Performance Killer. Harvard Business Review. Access mode: https://hbr2.org/2006/10/ sleep-deficit-the-performance-killer

[10] Guidotti, T. (2016). Health Risks and Fair Compensation in the Fire Service. Springer.

[11] Healy, M. (2017). Firefighters and sleep apnea: What you need to know. Access mode: https://www.linkedin.com/pulse/ firefighters-sleep-apnea-what-you-need-know-michael-healy

[12] Hom, M., Stanley, I., Rogers, M., Tzoneva, M., Bernert, R., \& Joiner, T. (2016). The Association between Sleep Disturbances and Depression among Firefighters: Emotion Dysregulation as an Explanatory Factor. Journal of Clinical Sleep Medicine, 12(2), 235-245. doi: 10.5664/jcsm.5492

[13] IAFF FireFighters. Access mode: https://client.prod.iaff.org/ \#page=HealthAndSafety rescuers such occupational diseases as cardiovascular disease (arterial hypertension, heart attacks), diabetes and depressive disorders, which can be distributed in the following way: - younger firefighters are inclined to the development of depression and various depressive mood disorders in them; - middle-aged firefighters are more likely to develop in them cardiovascular disease and diabetes due to a high BMI rate; - older rescuers have an inclination to heart attacks and getting into accidents and dangerous situations. A number of protective (preventive) measures should be worked out in order to minimize the negative impact of occupational factors leading to the development of certain occupational illnesses in professional firefighters. Sleep education and sleep hygiene should become firefighters' priorities on their jobs.

[14] llyin, Ye. P. (2012). Psychology of risk. Piter: SPb.

[15] Imeri, L., \& Opp, M. R. (2009). How (and why) the immune system makes us sleep. Nature Reviews Neuroscience, 10(3), 199-210. doi: $10.1038 / \mathrm{nrn} 2576$

[16] Insomnia. Access mode: http://www.euro.who.int/

[17] Kim, H., Jung, S., Choi, Y., Kim, S., Joung, H., Kim, E., \& Kim, H. (2017). Sleep Patterns of Firefighters with Shift Working Schedules in Seoul Metropolitan Area. Sleep Medicine Research, 8(2), 68-75. doi: 10.17241/smr.2017.00059

[18] Kovalenko, V. M. (2009). Guidelines in cardiology. Kyiv : MORION.

[19] Kovalzon, V. M. (2011). Basics of somnology. Physiology and neurochemistry of the cycle "vigilance-sleep". Moscow : VINOM.

[20] Levin, Ya.V., \& Poluektov, M. G. (2013). Somnology and sleep medicine. Selected lectures. Moscow : MEDFORUM.

[21] Mischenko, L. A., \& Svischenko, Ye. P. (2002). Circadian rhythms of neurohumoral regulatory systems determining diurnal profile of blood pressure. Ukrainian Cardiology Journal. Access mode: http://journal.ukrcardio.org/ cardio archive/2002/1/mishchenko.htm

[22] Mokhlesi, B., Finn, L., Hagen, E., Young, T., Hla, K., Cauter, V., \& Peppard, P. (2014). Obstructive Sleep Apnea during REM Sleep and Hypertension. Results of the Wisconsin Sleep Cohort. American Journal of Respiratory and Critical Care Medicine, 190(10), 1158-1167. doi: 10.1164/rccm.201406$1136 \mathrm{OC}$

[23] Pamidi, S., Wroblewski, K., Stepien, M., Sharif-Sidi, K., Kilkus, J., Whitmore, H., \& Tasali, E. (2015). Eight Hours of Nightly Continuous Positive Airway Pressure Treatment of Obstructive Sleep Apnea Improves Glucose Metabolism in Patients with Prediabetes. A Randomized Controlled Trial. American Journal of Respiratory and Critical Care Medicine, 192(1), 96-105. doi: 10.1164/rccm.201408-15640C

[24] Paul, K. N., Saafir, T. B., \& Tosini, G. (2009). The role of retinal photoreceptors in the regulation of circadian rhythms. Reviews in Endocrine and Metabolic Disorders, 10(4), 271-278. doi: 10.1007/s11154-009-9120-x

[25] Perrot, D. (2014). Stress operationnel chez le Sapeur-pompier. Identification, facteurs, risques et traitements. Caen: Service D?partemental d'Incendie et de Secours du Calvados (SDIS 14).

[26] Pierres, V., Lefloch, H., Sauvet, F. \& Chennaoui, M. (2016). Evaluation de l'impact des troubles du sommeil au sein de la 
Brigade des sapeurs-pompiers de Paris (BSPP). Medicine du Sommeil, 13(1), 19-20. doi: 10.1016/j.msom.2016.01.057

[27] Sullivan, J., O'Brien, C., Barger, L., Rajaratnam, S., Czeisler, C., \& Lockley, S. (2017). Randomized, Prospective Study of the Impact of a Sleep Health Program on Firefighter Injury and Disability. SLEEP, 40(1), 1-10. doi: 10.1093/sleep/zsw001 [28] Walker, M. (2018). Why We Sleep. Penguin Books.
[29] World Health Organization Regional Office for Europe and the European Centre for Environment and Health Bonn Office (2004). WHO technical meeting on sleep and health. Access mode: https://www.ilo.org/wcmsp5/groups/public/ed_protect/-protrav/-safework/documents/publication/ wcms_118388.pdf

\section{ПОРУШЕННЯ СНУ Й ПОВ'ЯЗАНІ З НИМИ ПРОФЕСІЙН ЗАХВОРЮВАННЯ В УКРАЇНСЬКИХ ПОЖЕЖНИХ-РЯТУВАЛЬНИКІВ Сухолєнцев О. М., Крайсвітній О. І., Ковальчук В. Б., Черній В. П., Ковальчук Н.Д.}

Порушення сну являють собою один із основних професійно обумовлених факторів для пожежних-рятувальників, який знижує їхню працездатність і сприяє розвитку таких відхилень у стані здоров'я, як серцево-судинні захворювання, діабет, депресивні стани. Метою цього дослідження $є$ збір попередніх даних стосовно профресійного здоров'я українських пожежних з акцентом на показники якості сну. Для виявлення порушень сну ми скористалися наступними опитувальниками: Пітсбурзький показник якості сну (PSQI), Показник тяжкості інсомнії (ISI), Епвортська шкала сонливості (ESS), Шкала втомлюваності (FSS), Стенфордська шкала сонливості (SSS), Берлінський опитувальник (BQSA). Cmaтистичне опрацювання даних здійснювалось за допомогою точного критерія Фішера, статистичного методу, який широко застосовується в медичних дослідженнях для малих вибірок. Отримані результати підтверджують наявність певних закономірностей. По-перше, типові для пожежної галузі порушення сну було виявлено серед працівників оперативнорятувальної служби міста Кропивницького: денна втомлюваність, низька якість сну, інсомнія, апное, СНн (синдром неспокійних ніг), денна сонливість та низький рівень пильності. По-друге, особи, що страждають від вище зазначених порушень сну, мають вищий рівень ризику виникнення серцево-судинних, метаболічних захворювань, депресивних розладів. Також нами визначено, що зазначені порушення сну стали причиною підвищеної імпульсивності і зниженого рівня працездатності. По-третє, у нашому дослідженні підкреслюється значущість завчасного виявлення $і$ корекції порушень сну як профрілактичного заходу щодо розвитку зазначених вище захворювань. Роз'яснювальна робота стосовно гігієни сну має проводитися серед українських пожежних задля того, щоб вони могли покращити свій сон, що безсумнівно виявиться в усіх аспектах їхнього професійного здоров'я і добробуту. Щорічні дослідження якості сну мають проводитися регулярно $з$ метою відстежити динаміку статистичних показників з цієї теми.

Ключові слова: порушення сну, працездатність, професійне здоров'я, професійне захворювання, профрілактична (превентивна) медицина.

\section{НАРУШЕНИЯ СНА И СВЯЗАННЫЕ С НИМИ ПРОФЕССИОНАЛЬНЫЕ ЗАБОЛЕВАНИЯ У УКРАИНСКИХ ПОЖАРНЫХ- СПАСАТЕЛЕЙ \\ Сухоленцев А. Н., Крайсвитний А. И., Ковальчук В. Б., Черний В. П., Ковальчук Н. Д.}

Нарушения сна представляют собой один из основных профессионально-обусловленных факторов для пожарныхспасателей, который снижает их работоспособность и способствует развитию таких отклонений в состоянии здоровья, как сердечно-сосудистые заболевания, диабет и депрессивные состояния. Целью настоящего исследования является сбор предварительных данных относительно профессионального здоровья украинских пожарных с акцентом на показатели качества сна. Для выявления нарушений сна нами использовались опросники: Питтсбургский показатель качества сна (PSQI), Показатель тяжести инсомнии (ISI), Эпвортская шкала сонливости (ESS), Стенфордская шкала сонливости (SSS), Шкала утомляемости (FSS), Берлинский опросник (BQSA). Статистическая обработка данных осуществлялась при помощи точного критерия Фищера, статистического метода, который повсеместно применяется в медицинских исследованиях с малыми выборками. Полученные результаты подтверждают наличие определенных закономерностей. Во-первых, типичные для пожарной отрасли нарушения сна были выявлены среди работников оперативно-спасательной службы города Кропивницкого: дневная утомляемость, низкое качество сна, инсомния, апноэ, СБН (синдром беспокойных ног), дневная сонливость и низкий уровень бдительности. Во-вторых, лица, страдающие от вышеуказанных нарушений сна, имеют более высокий уровень риска возникновения сердечно-сосудистых, метаболических заболеваний, и депрессивных расстройств. Также, нами определено, что вышеуказанные нарушения сна стали причиной повышения импульсивности и снижения уровня работоспособности. B-третьих, в нашем исследовании подчеркивается значимость раннего выявления и коррекции нарушений сна как профилактической меры против развития вышеуказанных заболеваний. Разъяснительная работа относительно гигиены сна должна проводиться среди украинских пожарных с тем, чтобы они могли улучшить свой сон, что, несомненно, скажется на всех аспектах их профессионального здоровья и благосостояния. Ежегодные исследования качества сна должны проводиться регулярно с целью отследить динамику статистических показателей по интересующей нас теме.

Ключевые слова: нарушения сна, работоспособность, профессиональное здоровье, профессиональное заболевание, профилактическая (превентивная) медицина. 